\title{
CAPITAL BUDGETING ANALYSIS OF INVESTMENT PROJECT FEASIBILITY IN PT INTEGRA INDOCABINET TBK,
}

\author{
Adetia Wardani ${ }^{1}$, Ani Wulandari ${ }^{2}$ \\ adetiawardani@gmail.com ${ }^{1}$, ani.wulandari@narotama.ac.id ${ }^{2}$ \\ Departement of Management, Faculty of Economics and Business, Narotama University \\ Jl. Arief Rahman Hakim 51, Surabaya, Indonesia ${ }^{1,2}$
}

\begin{abstract}
This research is a case study conducted in one of the property companies in Sidoarjo, East Java, namely PT Integra Indocabinet Tbk ,. Based on secondary data, PT Integra Indocabinet has increased sales and profits from 2014 - 2018. Therefore, the owners want to expand their expansion by adding new factory facilities so they can get more optimal profits and can increase exports abroad. The research aims to provide assistance in the form of suggestions for decision making between feasible or not worthy of the investment carried out. Based on the calculation, obtained an NPV value of $195,510,594,699 \geq 0$ which means it is feasible to run, an IRR of $22 \%>$ hurdle rate $(10 \%)$ which means it is feasible to run; Payback Period is 4 years 3 months $>5$ years which means it is feasible to be implemented; The Profitability Index is $1.98>0$, which means it's worth running. The results of the analysis show that using Capital Budgeting techniques can be seen that investment decisions for expansion are feasible.
\end{abstract}

Keywords: Capital Budgeting, Investment Decisions, NPV, IRR, PB, PI

\section{INTRODUCTION}

\section{A. Background Research The}

Purpose of investing is to obtain large profits with manageable risks and in hopes of optimizing the value of the company. Investment decisions affect the value of the company, and this shows that there are a number of investments that will get a surplus if the company is able to make the right investment decisions. According to (Triastuti, Ningsih, \& Diba, 2018) The surplus obtained will contribute to cashflow, then accumulated on increasing the profit of the company, conversely if the investment decision does not affect the value of the company, it means that the company has a deficit for a number of investments that will reduce equity and ultimately will reduce the value of the company. In the company's business turnover, capital budget becomes an important tool in allocating resources within a company. This is inseparable from the role of a manager in making rational economic decisions so that the budget process can be made effective. Decisions taken can then have a significant impact on the company. Therefore, not a few decision makers escalate their commitment to a series of poor project performance (Scientific, Volume, \& Agustina, 2011). According to (Van Horne and Wachowicz, 2005) capital budgeting is the process of identifying, analyzing, and selecting various projects whose returns (cash flows) are estimated to be received more than one hundred. Whereas according to Suadana (2011), capital budgeting is the minimum level of income that the capital owner implies. So from the point of view of companies that obtain funds, the level of income indicated is the cost of funds obtained by the company. The size of the capital of a company depends on the source of funds used by the company to finance investments, especially the source of long-term funds. There are various forms of investment including: the establishment of new businesses, expanding businesses, or expanding finance to rehabilitate machines that have decreased efficiency, rebuilding machinery (rebuilding), changing distribution channels from distribution through intermediaries to distribution through agents / branches owned by the company itself, conducting research to find a more efficient process, creating new products and improving management information systems.

Furniture manufacturer, PT Integra Indocabinet Tbk (WOOD) has prepared several expansion agendas this year so that its performance will increase and is known to be adding production facilities for manufacturing new products, such as wooden blinds or wooden window blinds to metal furniture with metal combinations. For this reason, WOOD has again built a new plant facility by utilizing land that has been purchased from the IPO results in 2017. PT Integra Indocabinet has a production capacity of around 10 containers per month or 1,650 cubic meters of wood per year, both wooden blinds and iron furniture targeting foreign markets namely the United States (US). For this reason WOOD is reportedly planning to 
release capital expenditure $\mathrm{Rp} 200$ billion in(capex) this year to support the expansion needs.

From the explanation above shows the importance of finance, the topic I will examine is about Capital Budgeting to measure the feasibility of expansion to be carried out by PT Integra Indocabinet, and I chose the following title "ANALYSIS CAPITAL BUDGETING FEASIBILITY OF INVESTMENT PROJECTS IN PT INTEGRA INDOCABINET Tbk"

\section{PROBLEM FORMULATION}

1. What is the application of the Capital Budgeting method in calculating the feasibility of anproject investmentof PT Integra Indocabinet?

2. How to assess the feasibility of an investment project of PT Integra Indocabinet through Payback analysis Period (PBP)?

3. How to assess the feasibility of PT Integra Indocabinet's investment project through Net analysis Present Value (NPV)?

4. How to assess the feasibility of the PT Integra Indocabinet investment project through the analysis of Profitability index (PI)?

5. How to assess the investment feasibility of PT Integra Indocabinet through the analysis of the Internal Rate of Return (IRR)?

\section{OBJECTIVES OF RESEARCH}

1. To analyze the application of the capital budgeting method in calculating the feasibility of the investment project carried out by PT Integra Indocabinet.

2. To assess the feasibility of investment projects carried out by PT Integra Indocabinet.

\section{BENEFITS OF RESEARCH}

1. For Authors

This research is expected to expected to be a means to increase knowledge and insight about what techniques are used in conducting capital budgeting analysis and can apply the theories obtained during college.

2. For Universities

The results of this study are capable and can be used as a reference for writing and further researchers, especially in inventory case studies.

3. For Companies

Companies can find out whether this investment project is feasible or not.

\section{E. RESEARCH METHODS}

1. Approach

research carried out is descriptive research, namely by collecting, classifying, analyzing and interpreting data relating to the problems faced and comparing technical knowledge (primary data) with the actual conditions in the company to then draw conclusions .

\section{Research Places}

This research was conducted at the research address at PT Integra Indocabinet Sidoarjo Jl. Raya Betro 678, Sedati, Sidoarjo, East Java.

\section{Definition Of Operational Variables}

Capital Budgeting Capital budgeting is the process of identifying, analyzing and selecting investment activities whose returns (cash flows) are expected to be more than one year.

\section{Data Types And Sources}

Type of data used in this study is qualitative data, in the form of financial report documents of PT. Integra Indocabinet. The data is secondary data, namely data obtained from the company in the form of financial statements of PT Integra Indocabinet.

\section{RESULTS AND DISCUSSION}

\section{INITIAL INVESTMENT}

PT Integra Indocabinet plans to build afactory wooden blind for the United States market. Besides increasing revenue, the construction of this factory, said Wang, is to increase the utilization of wood produced from the company's forests. A factory planned to be built in Sidoarjo and has a capacity of 6,500 square meters. And PT Integra Indocabinet has prepared around Rp 200,000,000,000 for the construction of this factory. 
a. Cash Flow Report

One of the important things in the issue of investment policy is to make an estimate of the expenditure of money that will be received from the investment in the future. To evaluate various alternatives for budgeting capital goods / investments, companies must determine the appropriate cash flow, namely data regarding net cash flow from an investment.

Cash Flow Statement

PT Integra Indocabinet Tbk

for the Year Ended December2014-2018

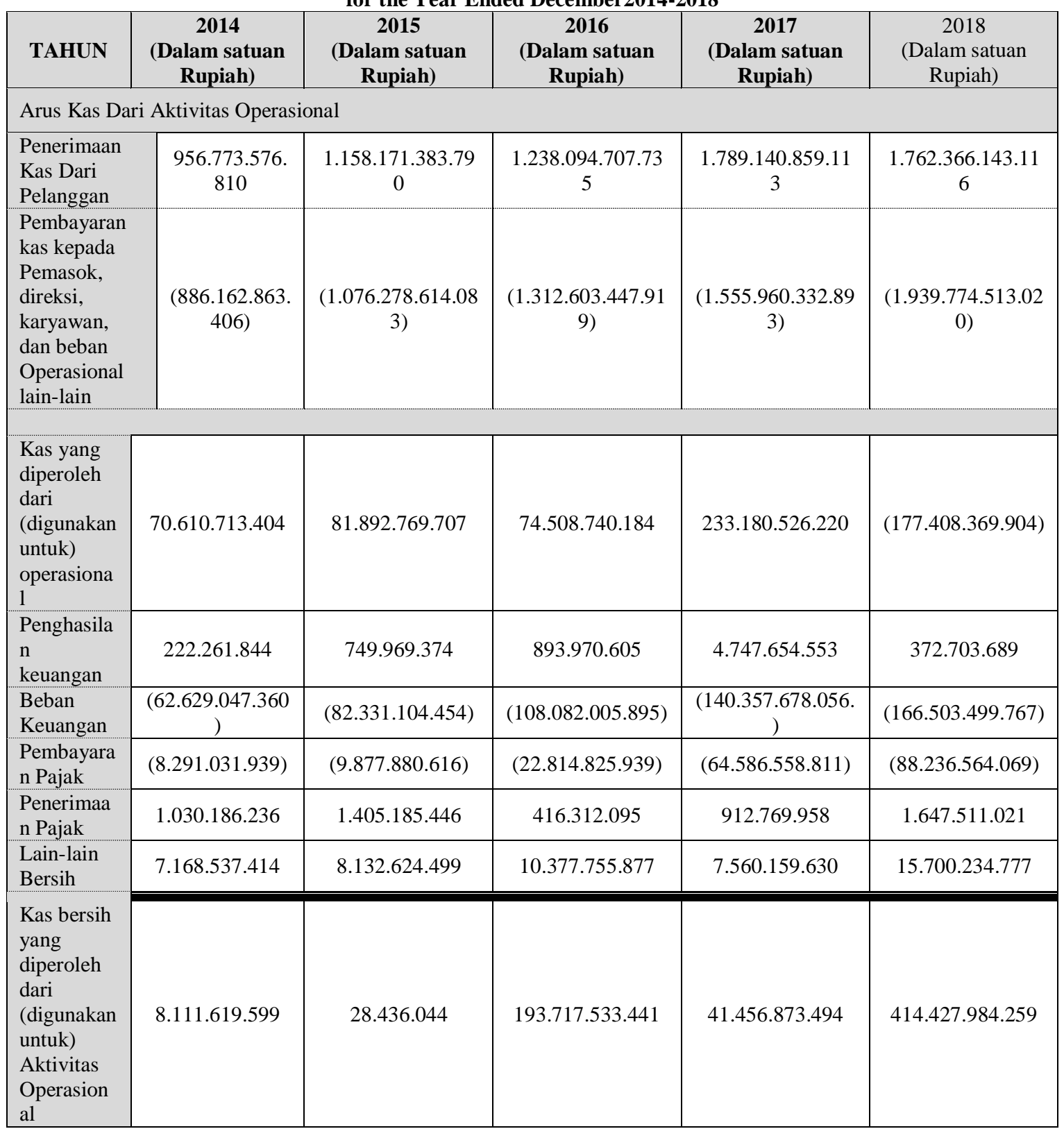

(Source: Financial Statements of PT Integra Indocabinet Tbk: 2014-2015)

And for the next step is to take into account Depreciation, payback period, Average rate of return (ARR), Net Present Value at 10\% discount rate, Profitability Index at 10\% discount rate, and finally the Internal Rate of Return.

b. Depreciation

The economic life of an investment is estimated at 5 years using the straight-line method and the 
calculation details are as follows:

Table.Income before Depreciation

\begin{tabular}{|c|c|c|c|c|c|}
\hline & 2014 & 2015 & 2016 & 2017 & 2018 \\
\hline $\begin{array}{c}\text { Profit } \\
\text { Before } \\
\text { depreciatio } \\
n\end{array}$ & $\begin{array}{c}\mathrm{Rp} \\
8.111 .619 .599\end{array}$ & $\begin{array}{c}\mathrm{Rp} \\
28.436 .044\end{array}$ & $\begin{array}{c}\mathrm{Rp} \\
193.717 .533 .441\end{array}$ & $\underset{\text { Rp }}{41.456 .873 .494}$ & $\begin{array}{c}\mathrm{Rp} \\
414.427 .984 .259\end{array}$ \\
\hline
\end{tabular}

(Source: Author: 2019)

Depreciation = Initial Investment: Economic Age

Table. Depreciation With Straight-Line Method

\begin{tabular}{|r|l|l|l|}
\hline $\begin{array}{c}\text { AKHIR } \\
\text { TAHUN } \\
\text { KE }\end{array}$ & \multicolumn{1}{|c|}{$\begin{array}{c}\text { BIAYA } \\
\text { PENYUSUTUAN }\end{array}$} & $\begin{array}{c}\text { AKUMULASI BIAYA } \\
\text { PENYUSUTAN }\end{array}$ & NILAI BUKU \\
\hline 1 & $\mathrm{Rp} 40.000 .000 .000$ & $\mathrm{Rp} 40.000 .000 .000$ & $\mathrm{Rp} 160.000 .000 .000$ \\
\hline 2 & $\mathrm{Rp} 40.000 .000 .000$ & $\mathrm{Rp} 80.000 .000 .000$ & $\mathrm{Rp} 120.000 .000 .000$ \\
\hline 3 & $\mathrm{Rp} 40.000 .000 .000$ & $\mathrm{Rp} 120.000 .000 .000$ & $\mathrm{Rp} 80.000 .000 .000$ \\
\hline 4 & $\mathrm{Rp} 40.000 .000 .000$ & $\mathrm{Rp} 160.000 .000 .000$ & $\mathrm{Rp} 40.000 .000 .000$ \\
\hline 5 & $\mathrm{Rp} 40.000 .000 .000$ & $\mathrm{Rp} 200.000 .000 .000$ & $\mathrm{Rp}$ \\
\hline
\end{tabular}

(Source: Author: 2019)

Table. Cash In Flow

\begin{tabular}{|l|c|c|c|c|c|}
\hline TAHUN & $\begin{array}{c}\mathbf{1} \\
(\mathbf{R p})\end{array}$ & $\begin{array}{c}\mathbf{2} \\
(\mathbf{R p})\end{array}$ & $\begin{array}{c}\mathbf{3} \\
(\mathbf{R p})\end{array}$ & $\begin{array}{c}\mathbf{4} \\
(\mathbf{R p})\end{array}$ & $\begin{array}{c}\mathbf{5} \\
(\mathbf{R p})\end{array}$ \\
\hline $\begin{array}{l}\text { PROFIT } \\
\text { BEFORE } \\
\text { DEP. }\end{array}$ & 8.111 .619 .599 & 28.436 .044 & 193.717 .533 .441 & 41.456 .873 .494 & 414.427 .984 .259 \\
\hline $\begin{array}{l}\text { LESS. } \\
\text { DEP }\end{array}$ & $(40.000 .000 .000)$ & $(40.000 .000 .000)$ & $(40.000 .000 .000)$ & $(40.000 .000 .000)$ & $(40.000 .000 .000)$ \\
\hline $\begin{array}{l}\text { PROFIT } \\
\text { BEFORE } \\
\text { TAX }\end{array}$ & $(31.888 .380 .401)$ & $(39.971 .563 .956)$ & 153.717 .533 .441 & 1.456 .873 .494 & 374.427 .984 .259 \\
\hline $\begin{array}{l}\text { TAX } \\
\text { @15\% }\end{array}$ & $(4.783 .257 .060)$ & $(5.995 .734 .593)$ & 23.057 .630 .016 & 218.531 .024 & 56.164 .197 .639 \\
\hline $\begin{array}{l}\text { NET } \\
\text { PROFIT }\end{array}$ & $(27.105 .123 .341)$ & $(33.975 .829 .363)$ & 130.659 .903 .425 & 1.238 .342 .470 & 318.263 .786 .620 \\
\hline $\begin{array}{l}\text { LESS. } \\
\text { DEP }\end{array}$ & 40.000 .000 .000 & 40.000 .000 .000 & 40.000 .000 .000 & 40.000 .000 .000 & 40.000 .000 .000 \\
\hline $\begin{array}{l}\text { CASH } \\
\text { INFLOW }\end{array}$ & 12.894 .876 .659 & 6.024 .170 .637 & 170.659 .903 .425 & 41.238 .342 .470 & 358.263 .786 .620 \\
\hline
\end{tabular}

(Source: Author : 2019)

\section{Evalution Method of Investment Worthiness}

\section{a. Payback The}

Payback Period period shows how long the period of time required to return the investment value by dividing the total initial investment with the total proceeds per year. At this Investment the maximum proceeds taking into account its economic age is estimated to be 5 years. Furthermore, PBP calculation with the assumption that the proceeds are constant (annuity) per year, then the PBP can be calculated as follows:

Table. Payback forPeriod

\begin{tabular}{|c|l|}
\hline YEARS & \multicolumn{1}{|c|}{ CF (Cash Flow) } \\
\hline 0 & $\operatorname{Rp}(200.000 .000 .000)$ \\
\hline 1 & $\mathrm{Rp} 12.894 .876 .659$ \\
\hline 2 & $\mathrm{Rp} \quad 6.024 .170 .637$ \\
\hline
\end{tabular}




\begin{tabular}{|c|cc|}
\hline 3 & $\mathrm{Rp}$ & 170.659 .903 .425 \\
\hline 4 & $\mathrm{Rp}$ & 41.238 .342 .470 \\
\hline 5 & $\mathrm{Rp}$ & 358.263 .786 .620 \\
\hline
\end{tabular}

(source: Author: 2019)

$\begin{aligned} \mathrm{PB} & =4 \text { years }+\frac{\operatorname{Rp} 10.421 .049 .279}{\operatorname{Rp} 41.238 .342 .470} \\ & =4 \text { years }+0,25 \\ & =4,25 \text { years }(4 \text { years, and } 3 \text { months })\end{aligned}$

Taking into account the PBP results mentioned above for 4.3 years while the maximum proceeds from this stone breaking unit are 5 years, then the rate of return of the investment value is faster than the maximum proceeds so that PT Integra Indocabinet Tbk's investment is feasible.

\section{b. Net Present Value (NPV)}

Net present value takes into account the present net value on the basis of the time value of future money to be valued at the present time. This will be obtained from the difference from the present value of proceeds with the present value of initial investment taking into account the economic age and a certain discount rate. Here's the calculation:

Table. Net Present Value

\begin{tabular}{|c|c|c|c|}
\hline Tahun & CF & PVF $10 \%$ & PV \\
\hline 0 & $\mathrm{Rp}(200.000 .000 .000)$ & 1 & $\mathrm{Rp}(200.000 .000 .000)$ \\
\hline 1 & Rp 12.894.876.659 & 0,909 & $\mathrm{Rp} \quad 11.721 .442 .883$ \\
\hline 2 & $\mathrm{Rp}$ 6.024.170.637 & 0,826 & $\mathrm{Rp} \quad 4.975 .964 .946$ \\
\hline 3 & $\mathrm{Rp} 170.659 .903 .425$ & 0,751 & $\mathrm{Rp} \quad 128.165 .587 .472$ \\
\hline 4 & $\mathrm{Rp} 41.238 .342 .470$ & 0,683 & $\mathrm{Rp} \quad 28.165 .787 .907$ \\
\hline 5 & $\mathrm{Rp} 358.263 .786 .620$ & 0,621 & $\mathrm{Rp} \quad 222.481 .811 .491$ \\
\hline
\end{tabular}

(source: Author: 2019)

$$
\begin{aligned}
\mathrm{NPV} & \frac{\sum C F}{(1+i)^{n}}-\mathrm{CI} \\
& =\operatorname{Rp} 395.510 .594 .699-\operatorname{Rp} 200.000 .000 .000 \\
& =\operatorname{Rp} 195.510 .594 .699
\end{aligned}
$$

The results of the above table shows that investment plans can be run because the NPV value indicates a positive number that is equal to Rp 195510594 699, so that this investment financially feasible to run.

\section{c. Profitability Index (PI)}

By using the $10 \%$ discount rate above, then profitability index (PI), can be calculated by comparing the PV of Cash Inflow with PV of initial Investment. From the results of the NPV calculation above, the following results are obtained:

$$
\begin{aligned}
\mathrm{PI} & =\frac{\text { Present Value Of Cash In Flow }}{\text { Present value of cash out flow }} \\
& =\frac{R p 395.510 .594 .699}{R p 200.000 .000 .000} \\
& =1,98
\end{aligned}
$$

Results of calculation of profitability index (PI) obtained a value of 1,98 , meaning greater than number 1 , so this investment is feasible to run. 


\section{d. Internal Rate Of Return (IRR) The}

internal rate of return calculates the interest rate that equals the present value of the proceeds. IRR is used as a benchmark for the level of the project's ability to produce proceeds to the same as the initial investment then compared to the level of cost of capital. To obtain this value, an interpolation approach is carried out by calculating a positive NPV with a negative NPV, so a certain discount factor will be obtained which results in an NPV value equal to 0 , with the formula:

Table. Internal Rate Of Return

\begin{tabular}{|c|c|c|c|c|c|}
\hline Tahun & CF & PVF $10 \%$ & PV & PVF8\% & PV \\
\hline 0 & $(200.000 .000 .000)$ & 1 & $(200.000 .000 .000)$ & 1 & $(200.000 .000 .000)$ \\
\hline 1 & 12.894 .876 .659 & 0,909 & 11.721 .442 .883 & 0,926 & 11.940 .655 .786 \\
\hline 2 & 6.024 .170 .637 & 0,826 & 4.975 .964 .946 & 0,857 & 5.162 .714 .236 \\
\hline 3 & 170.659 .903 .425 & 0,751 & 128.165 .587 .472 & 0,794 & 135.503 .963 .319 \\
\hline 4 & 41.238 .342 .470 & 0,683 & 28.165 .787 .907 & 0,735 & 30.310 .181 .715 \\
\hline 5 & 358.263 .786 .620 & 0,621 & 222.481 .811 .491 & 0,681 & 243.977 .638 .688 \\
\hline
\end{tabular}

(source: Author: 2019)

$\begin{aligned} \text { IRR } & =\text { Lower Rate }+\frac{\text { Positive NPV }}{\text { Positive NPV-Negativ NPV }}+\text { Different In Discount Rate } \\ & =8 \%+\frac{226.895 .153 .745}{226.895 .153 .745-195.510 .594 .699}+2 \\ & =8 \%+14 \\ & =22 \%\end{aligned}$

The IRR calculation results obtained at an IRR of $22 \%$, more the amount of interest used for the cost of capital from the initial investment is $10 \%$ percent, so this investment is feasible to run.

\section{CONCLUSIONS AND RECOMMENDATIONS}

follows:

Based on the results of the research that has been conducted, several conclusions can be taken as

1. Based on the results of financial analysis obtained from thecalculation of Payback period investment to be carried out by PT Integra Indocabinet Tbk, it is feasible to run because it shows PBP 4.3 year faster than the maximum period of 5 years.

2. Based on the results of a Net Present Value (NPV) positive, which is equal to $195,510,594,699$, then it is stated that this investment is feasible to carry out

3. Based on the results of the study, the Profitability Index (PI) of 1.98 is greater than 1, then this investment is stated feasible to run

4. Based on the results of the study show an IRR of $22 \%$ greater than the value ofcost of capital $10 \%$, then it is stated that this investment is feasible to run.

5. By observing the results of these quantitative values as the basis for making decisions through a capital budgeting approach through financial analysis, this investment is financially "WORTH" to run.

\section{Suggestion}

After describing some of the conclusions mentioned above, it is necessary to put forward some suggestions relating to investment in fixed assets that can be taken into consideration in decision making in the future. The suggestions that can be put forward are as follows:

1. For Companies

a. Decisions regarding investment in fixed assets are decisions that greatly determine the success of the company, because decisions regarding investment are related to large funds and a relatively long time. 
b. Companies in investing their funds in an investment proposal need to analyze whether the investment proposal is really feasible or not to be implemented, because then the risk of losses to be suffered by the company will be smaller.

c. The results of the calculation of investment feasibility analysis indicate that this investment is feasible to be implemented.

2. For Further Researchers

It is better for future researchers to conduct research related to the feasibility of investment proposals for fixed assets should pay attention to aspects that can affect the feasibility of the proposed investment, so the results obtained will be correct really valid, the proposed investment can provide maximum benefits and does not have a negative impact on the company that will make the proposed investment .

\section{REFERENCES}

Arikunto, S. (2006). Metode Penelitian Kualitatif. Jakarta: Bumi Aksara.

Ilmiah, J., Volume, E., \& Agustina, Y. (2011). ISSN No . 1978-6034 Decision for Reinvestment in Capital Budget : Material and non Material Sanction as Antecedent Keputusan untuk Terus Reinvestment pada Anggaran Modal : Sanksi Material dan Non Material sebagai Antecedent Pendahuluan Metode Penelitian, 5(1978).

Nazir, M. (2014). Metode Penelitian. Bogor: Ghalia Indonesia.

Noor, J. (2011). “Metode Penelitian : Skripsi, Tesis, Disertasi, dan Karya Ilmiah.” Jakarta: Kencana Prenada Media Group.

Satori, Djam'an dan Komariah, A. (2014). Metodologi Penelitian Kualitatif. Bandung: Alfabeta.

Sugiyono. (2013). Metode Penelitian Pendidikan Pendekatan Kuantitatif, Kualitatif, dan R\&D. Bandung: Alfabeta.

Sugiyono. (2014). Metode Penelitian Kuantitatif Kualitatif dan R\&D. Bandung: Alfabeta.

Sugiyono. (2017). Metode Penelitian Kuantitatif, Kualitatif, dan R \& D. Bandung: Alfabeta.

Sutopo, H. B. (2005). Metodologi Penelitian Kualitatif : Dasar teori dan Terapannya dalam Penelitian. Surakarta: Universitas Sebelas Maret.

Triastuti, H., Ningsih, K., \& Diba, S. F. (2018). ANALISIS CAPITAL BUDGETING DALAM

MENINGKATKAN KEPUTUSAN INVESTASI PADA PT . SAMUDERA INDONESIA, 5(1), 38-44.

Van Horne dan Wachowicz. (2005). Analisis Roa Dan Roe Terhadap Profitabilitas Bank Di Bursa Efek Indonesia. Al-Masraf : Jurnal Lembaga Keuangan Dan Perbankan, 1(2), 222. Retrieved from http://journal.febi.uinib.ac.id/index.php/almasraf/article/view/57

Pudjiastuti, E. dan S. Husnan. 2006. Dasar-Dasar Manajemen Keuangan Edisi Kelima. UPP STIM YKPN. Yogyakarta. Prof. Dr. Dadjim Sinaga, M.M dan Dr. Herlina Juni Risna S.M.Si. 2013. Studi Kelayakan Investasi Pada Proyek dan bisnis dalam perspektif iklim investasi perekonomian Global: Teori dan Aplikasinya dalam menilai investasi modal dalam proyek dan bisnis). Mitra wacana Media. Jakarta.

Salim Basalamah, Murdifin, Syafri Syam. 1994. Penilaian Kelayakan Penanaman Modal. Edisi

Kedua.Gadjah Mada Universitas Press. Yogyakarta.

Santoso. 2008. Analisis Kelayakan Proyek (Investasi) Terhadap Penghasilan yang Diharapkan pada PT. Sinar Waluyo Bandar Lampung. Universitas Lampung. Lampung. Skripsi. Tidak dipublikasikan.

Sarwono, Jonathan. 2006. Metode Penelitian Kuantitatif dan Kualitatif. Yogyakarta: Graha Ilmu.

Setiadi, A. 2002. Peranan Penganggaraan Modal Untuk Meningkatkan Keuntungan Usaha Pabrik Tahu Sari Rasa. Jurnal Ilmu Pariwisata. Vol.4.Simamora, H. 2000. Akuntansi Basis Pengambilan Keputusan Bisnis; Jilid Kedua, Cetakan Pertama. Selemba Empat. Jakarta. 